\title{
The Effect of Cyclic-AMP on the Regulation of c-myc Expression in T Lymphoma Cells
}

\author{
Daniel A. Albert \\ Department of Medicine, University of Chicago, Chicago, Illinois 60637
}

\begin{abstract}
Myc is implicated in the control of growth in a variety of cell types. I investigated c-myc gene expression in several lymphoid cell lines to determine the response to cyclic AMP. Cyclic AMP causes a precipitous decline in c-myc message concentration that precedes $G 1$ cell cycle arrest in wild type S49 cells but not in $\mathrm{KIN}^{-}$cells that lack cAMP dependent PKA activity. In wild-type $S 49$ cells washout of cyclic AMP restores c-myc message levels within $2 \mathrm{~h}$ but does not relieve the $\mathbf{G 1}$ arrest until $10 \mathrm{~h}$ later. Transcription runoff studies demonstrate inhibition of both transcriptional initiation and prolongation of initiated transcripts. However, the degree of inhibition is insufficient to explain the absence of detectable myc message suggesting that the predominant effect of cyclic AMP is to destabilize the c-myc message. In contrast to wild-type cells, the "Deathless" mutant S49 cell line is viable when arrested in G1 by exposure to cyclic AMP and has preserved c-myc expression. Thus, in S49 cells down regulation of c-myc expression appears to be associated with loss of viability rather than $G 1$ cell cycle arrest. Interestingly, CEM human $T$ lymphoma cells do not arrest in G1 phase when exposed to cyclic AMP in spite of losing detectable c-myc gene expression. This suggests that in some $\mathbf{T}$ lymphoma cells c-myc gene expression may not be necessary for cell cycle progression and proliferation. (J. Clin. Invest. 1995. 95:1490-1496.) Key words: S49 • CEM • cell cycle • protein kinase $\mathbf{A} \cdot \mathbf{G 1}$
\end{abstract}

\section{Introduction}

The c-myc proto-oncogene encodes a $64-\mathrm{kD}$ protein that, when heterodimerized with a related protein MAX, is transcriptionally active, binding to the consensus sequence CACGTG $(1,2)$. This transcriptional activity is thought to relate to the putative role of c-myc in cell cycle progression and cell proliferation (3). $M y c$ gene expression is under complex regulation (reviewed in reference 4) with initiation at three different promoter initiation sites (P0, P1, P2) multiple promoter elements that may regulate transcription $(5,6,7)$ transcriptional attenuation after the first exon and rapid message turnover $(8,9)$. More recently c-myc has been implicated in an opposite role - that of programmed

Address correspondence to Daniel A Albert, Department of Medicine, University of Chicago, 5841 South Maryland Ave., Chicago, IL 60637. Phone: 312-702-6885; FAX: 312-702-3467.

Received for publication 4 August 1994 and in revised form 3 November 1994.

J. Clin. Invest.

(C) The American Society for Clinical Investigation, Inc.

0021-9738/95/04/1490/07 \$2.00

Volume 95, April 1995, 1490-1496 cell death (apoptosis). This effect, but not its mitogenic activity, can be blocked by the bc1-2 gene product $(10,11)$.

Cyclic AMP also has a dual role. In many cell types it is mitogenic, presumably through its ability to induce phosphorylation and activation of the cyclic AMP response element binding protein CREB $(12,13)$. In other cell types it is inhibitory causing G1 cell cycle arrest and cytotoxicity (14). Both of the properties require protein kinase A activity. Most recently, the inhibitory activity of cyclic AMP has been linked the glucocorticoid response (15). One of the effects of cyclic AMP in some cell types is to attenuate c-myc expression.

The purpose of this study is to characterize c-myc gene expression in response to cyclic AMP in several $\mathrm{T}$ lymphoid cell lines. The specific hypothesis I investigated is whether the cyclic AMP inhibition of cell cycle progression and cytotoxicity correlates with diminished c-myc gene expression.

\section{Methods}

Cell culture. S49 mouse T lymphoma cells were grown in DME in the presence of $10 \%$ heat-inactivated horse serum in a humidified atmosphere containing $10 \% \mathrm{CO}_{2}$ at $37^{\circ} \mathrm{C}$. CEM human $\mathrm{T}$ lymphoma cells were grown in RPMI media in the presence of $10 \%$ heat-inactivated fetal bovine serum in a humidified atmosphere containing $5 \% \mathrm{CO}_{2}$ at $37^{\circ} \mathrm{C}$. Experimental cultures were used during logarithmic growth at a density of $0.5-2.0 \times 10^{6}$ cells $/ \mathrm{ml}$.

RNA extraction. Total cellular RNA was extracted from cells using guanidine precipitation as previously described (16).

Northern blot analysis. RNA ( $20 \mu \mathrm{g} / \mathrm{lane})$ was fractionated onto a $1 \%$ agarose $/ 6 \%$ formaldehyde gel by electrophoresis then transferred to a Hybond-N+ (Amersham, Arlington Heights, IL) nylon membrane by capillary action and fixed by incubation at $80^{\circ} \mathrm{C}$ for $2 \mathrm{~h}$. Northern blots were prehybridized for $4-6 \mathrm{~h}$ at $42^{\circ} \mathrm{C}$ in a solution containing $50 \%$ formamide, $5 \times$ Denhardt's, $5 \times$ SSC, $0.5 \%$ SDS, and $500 \mu \mathrm{g} / \mathrm{ml}$ denatured salmon sperm DNA. Hybridization was performed by the addition of 1.0 to $2.0 \times 10^{6} \mathrm{cpm} / \mathrm{ml}$ of ${ }^{32} \mathrm{P}$-labeled DNA probed to the prehybridization mix and incubating for $18 \mathrm{~h}$ at $42^{\circ} \mathrm{C}$. Blots were washed free of unbound probes by sequential exposure to $2 \times$ SSC, $0.1 \%$ SDS at $42^{\circ} \mathrm{C}$ for $30 \mathrm{~min}$ then $0.1 \times \mathrm{SSC}, 0.1 \% \mathrm{SDS}$ at $55-60^{\circ} \mathrm{C}$ for 30 min. After autoradiography at $-70^{\circ} \mathrm{C}$ bound probes were removed by incubating the blots in $0.1 \times \mathrm{SSC}, 0.1 \% \mathrm{SDS}$ at $100^{\circ} \mathrm{C}$ for $15 \mathrm{~min}$. The blots were then rehybridized to a different radiolabeled probe. Autoradiographic bands were quantitated by scanning densitometry using a Helena Cliniscan densitometer. In preliminary experiments a probe for the constitutively expressed enzyme GAPdH was used to quantitate RNA however, it was found to exhibit modest cell cycle variation. Additionally, each gel was stained with ethidium bromide to determine equal loading of samples and complete transfer to the nylon membrane.

Centrifugal elutriation. Cell cycle-specific populations were obtained by centrifugal elutriation as previously described (16). Briefly, 4 $\times 10^{8}$ cells were loaded at $9.5 \mathrm{ml} / \mathrm{min}$ onto a Beckman J2-21 centrifuge equipped with a JE-6 elutriation rotor at a speed of 2,000 rpm. Fractions of $50-100 \mathrm{ml}$ were removed as the flow rate was increased from 11.5 to $32 \mathrm{ml} / \mathrm{min}$.

Cell cycle analysis. Cell suspensions were centrifuged and resuspended in a solution of cold $\left(4^{\circ} \mathrm{C}\right)$ hypotonic staining solution $(0.05$ 


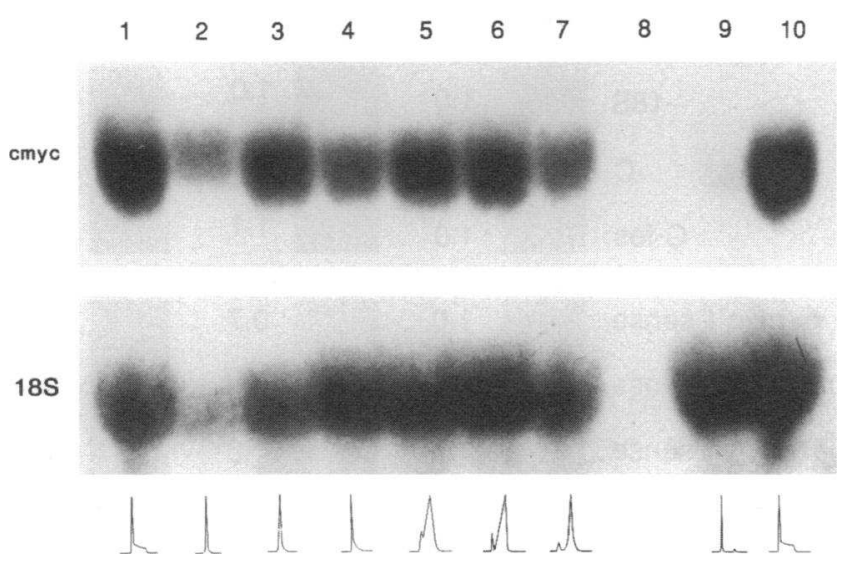

Figure 1. Cell cycle expression of the gene encoding c-myc. Exponentially growing $\mathrm{S} 49 \mathrm{~T}$ lymphoma cells were separated by centrifugal elutriation as described in Methods. Fractions were analyzed by cytofluorimetry of propidium iodide-stained cells. Fractions representative of different states of the cell cycle were selected and total cellular RNA (20 $\mu \mathrm{g} /$ lane) extracted for Northern blot analysis of messenger RNA coding for c-myc. On the left (lane 1 ) exponentially growing cells are $\sim 30 \%$ in $\mathrm{G} 1$ phase in comparison to the first elutriation fraction shown in lane 2 with over $90 \%$ in $\mathrm{G} 1$; lane $3,70 \%$; lane $7,3.4 \% \mathrm{G} 1,31 \% \mathrm{~S}$ phase, and $66 \% \mathrm{G} 2 / \mathrm{M}$. Lane 8 is blank. In the two lanes on the right, a cyclic AMP induced G1 cell-cycle-arrested population (lane 9, 88\% in G1) is compared with an exponentially growing population (lane 10). Equivalent loading of each lane was determined by ethidium bromide staining.

$\mathrm{mg} / \mathrm{ml}$ propidium iodide in $0.1 \%$ sodium citrate and $0.1 \%$ Triton $\mathrm{X}$ 100 ) for $15 \mathrm{~min}$. Flow cytometry was carried out (Becton-Dickinson, Rutherford, NJ) on an EPICS V analyzer (Coulter) equipped with a multiparameter data acquisition system (Coulter).

Nuclear runoff transcription assay. The nuclear runoff analysis was carried out as previously described (16). Nuclei were isolated on a sucrose cushion using the method described by Marzluff (17). DNA $(2 \mu \mathrm{g})$ for each of the probes was spotted on Hybond-N+ filters (Amersham) using a slot blot apparatus (Schleicher and Schuell, Keene, NH), except for $18 \mathrm{~S}$, where only $200 \mathrm{ng}$ was used. Densitometry was performed to quantitate the results.

RNase protection analysis. Total cellular RNA was analyzed by the RNase protection assay as described by Zinn (18). Samples (10 $\mu \mathrm{g}$ of total RNA plus RNA probe) were denatured at $85^{\circ}$ for $10 \mathrm{~min}$, followed by hybridization at $56^{\circ} \mathrm{C}$ for $12-14 \mathrm{~h}$. RNase treatment with $10 \mu \mathrm{g} / \mathrm{ml}$ RNase A and $500 \mathrm{u} / \mathrm{ml} \mathrm{T1} \mathrm{(Sigma} \mathrm{Chemical} \mathrm{Co.)} \mathrm{for} 1 \mathrm{~h}$ at $33^{\circ} \mathrm{C}$ was followed by addition of $10 \mu \mathrm{g} / \mathrm{ml}$ proteinase $\mathrm{K}$ for $10 \mathrm{~min}$ at $37^{\circ} \mathrm{C}$. RNase resistant fragments were analyzed on $5 \%$ polyacrylamide sequencing gel electrophoresis.

Materials. Plasmid pSV c-myc was obtained from American Type Culture Collection (ATCC cat no. 41029) Rockville Md. Single stranded M13 plasmids containing exon 1 and 2 sequences in the sense and antisense orientation were a gift of David Bentley (ICRF, London, UK). Plasmid probes were labeled with $\left({ }^{32} \mathrm{P}\right) \mathrm{dCTP}$ by random priming (Amersham, Multiprime Kit) (19). The remainder of the materials were commercially obtained (Sigma Chemical Co., St. Louis, MO).

\section{Results}

Cell cycle regulation of Myc gene expression. S49 mouse T lymphoma cells are transformed and originate from a mineral oil induced tumor in a BALB/c mouse. They have a doubling time of $14 \mathrm{~h}$ and during exponential growth $\sim 30 \%$ of cells are in $\mathrm{G} 1$ phase, $40 \%$ in $\mathrm{S}$ phase and $30 \%$ in $\mathrm{G} 2 / \mathrm{M}$ phase. Cells
A

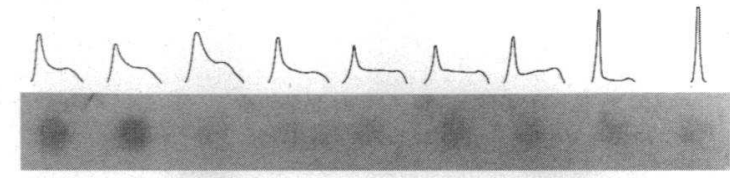

KIN

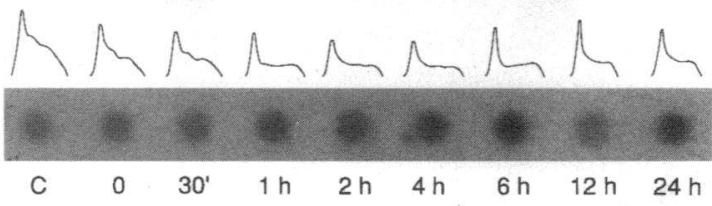

B

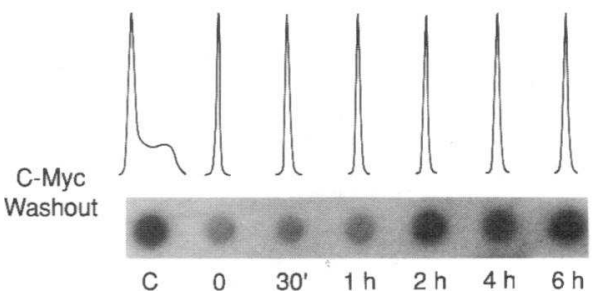

Figure 2. The effect of cyclic AMP on c-myc gene expression. Exponentially growing wild type $S 49$ cells $(A)$ were exposed to dibutyryl cyclic AMP (mM) for the times indicated and cells were examined by cytofluorimetry and northern dot blot analysis. The same analysis was performed for a PKA deficient $\mathrm{S} 49$ cell line, $\mathrm{KIN}^{-}$shown in the middle panel. In the $B$ wild-type $S 49$ cells were exposed to dibutyryl cyclic AMP ( $1 \mathrm{mM}$ ) for $24 \mathrm{~h}$ (time 0 ) and compared with exponentially growing cells $(c)$ and time points after removal of cyclic AMP.

may be fractionated by centrifugal elutriation as shown in Fig. 1 and samples assayed for c-myc gene expression by northern blot analysis. Exponentially growing S49 cells (lanes 1 and 10) have large amounts of c-myc messenger RNA that are easily detectable on Northern blots. There appears to be some cell cycle variability in the amount of c-myc message. However, when compared with the intensity of $18 \mathrm{~S}$ messenger RNA the variability in densitometric quantitation is $\sim 50 \%$ which is the same as the variation amongst samples from exponentially growing cells. Thus, there is no evidence for cell cycle variation in c-myc messenger RNA concentration in S49 cells. Under most circumstances $M y c$ protein levels are proportional to cmyc messenger RNA concentrations (4).

Effect of cyclic AMP on c-myc message level. Agents that elevate cyclic AMP generate G1 cell cycle arrest in S49 cells. This is reversible for at least $48 \mathrm{~h}$ but longer exposure results in cell death. Cyclic AMP treated cells are arrested in G1 phase and have undetectable levels of c-myc message (Fig. 1, lane 8) which is less than that of G1 elutriated cells (Fig. 1, lane 2). Densitometric quantitation indicates a 5-10-fold reduction in c-myc message. Time course Northern blot experiments (Fig. 2) reveal that c-myc message disappears in wild-type $S 49$ cells within $30 \mathrm{~min}$ of exposure to dibutyryl cyclic AMP $\sim 6 \mathrm{~h}$ before the first significant alteration in cell cycle distribution. Furthermore, in wild-type S49 cells, G1 arrested by exposure to dibutyryl cyclic AMP for $24 \mathrm{~h}$, washout experiments reveal a return of c-myc gene expression within $2 \mathrm{~h}$ which is $10 \mathrm{~h}$ before the cells begin to exit from G1. By contrast, $\mathrm{KIN}^{-} \mathrm{S} 49$ cells which lack PKA activity are unaffected by dibutyryl cyclic 

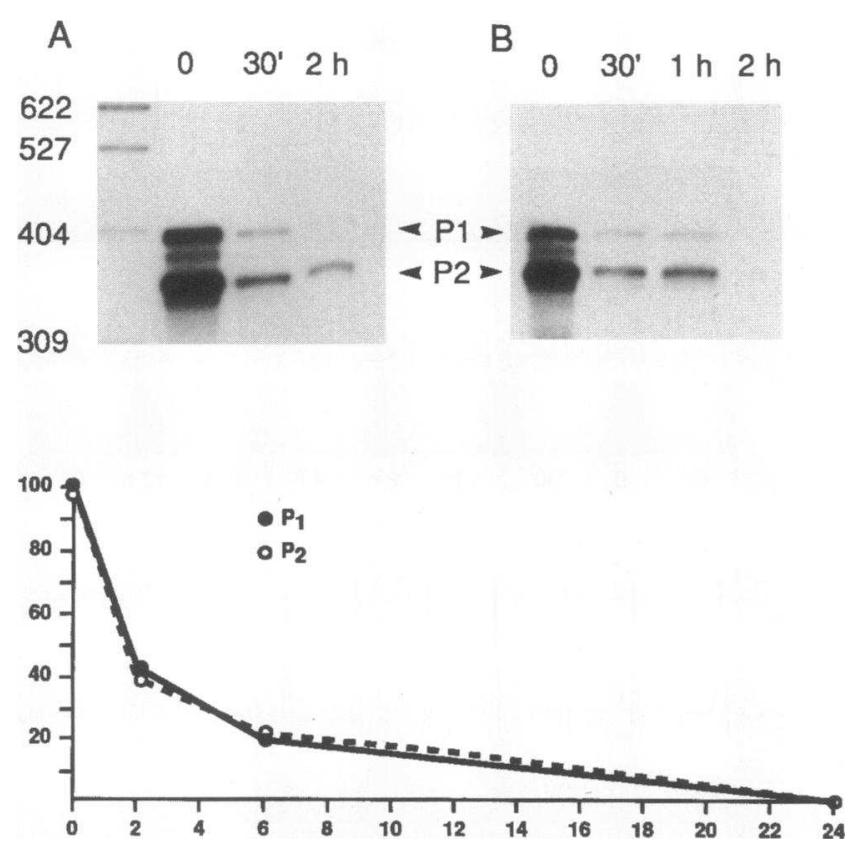

Figure 3. Analysis of c-myc mRNA after exposure of cells to actinomycin D or cyclic AMP. Total cellular RNA was extracted from exponentially growing $\mathrm{S} 49$ cells or cells treated with actinomycin $\mathrm{D}(5 \mu \mathrm{g} / \mathrm{ml})$ $(A)$ or dibutyryl cyclic AMP $(1 \mathrm{mM})(B)$ for the times shown. RNA was analyzed by RNase protection using $\alpha-{ }^{32} \mathrm{P}$ UTP-labeled RNA probe encompassing both $M y c$ promoters $\mathrm{P} 1$ and $\mathrm{P} 2$. The protected fragments were analyzed by electrophoresis in a denaturing $5 \%$ polyacrylamide gel. The bottom graph is an analysis of c-myc mRNA by radioactive scanning of a gel of an RNase protection assay after CEM cells were exposed to dibutyryl cAMP (1 $\mathrm{mM})$.

AMP both in terms of cell cycle distribution and c-myc message levels. Other S49 cell lines with different mutations segregate into these two classes depending on whether they possess PKA activity or not (data not shown). In other studies we have shown that (IL-2 dependent) mouse $T$ cell clones of both helper and suppressor/cytolytic phenotype are inhibited by cyclic AMP (19a).

Cyclic AMP versus actinomycin D. We compared the inhibition of expression of the c-myc gene by dibutyryl cyclic AMP with the RNA polymerase inhibitor actinomycin D. Initial studies indicated that the c-myc half-life using both of these inhibitors is $\sim 20$ min which correlates with published estimates of the c-myc messenger RNA half-life. We then used the RNase protection assay to determine if there is any difference in promoter use with these two agents. As shown in Fig. 3 both actinomycin D $(A)$ and cyclic AMP $(B)$ cause a prompt decrease in expression of the gene from both the $\mathrm{P} 1$ and $\mathrm{P} 2$ promoter sites. Densitometric analysis confirms a half-life of $\sim 20$ min with either of these agents.

The effect of cyclic AMP on transcription of c-myc. Transcriptional regulation of c-myc was analyzed by transcription run off assays using labelled nuclei from treated and untreated S49 cells and immobilized probes for both exon 1 and 2 of the c-myc gene in the sense and antisense orientation (Fig. 4). At $30 \mathrm{~min}$ of exposure there was no significant difference from control untreated nuclei (data not shown) however by $1 \mathrm{~h}$ there was a modest $(30 \%)$ decline in transcription of exon 1 in the sense orientation and a $40 \%$ decline in the transcription of exon

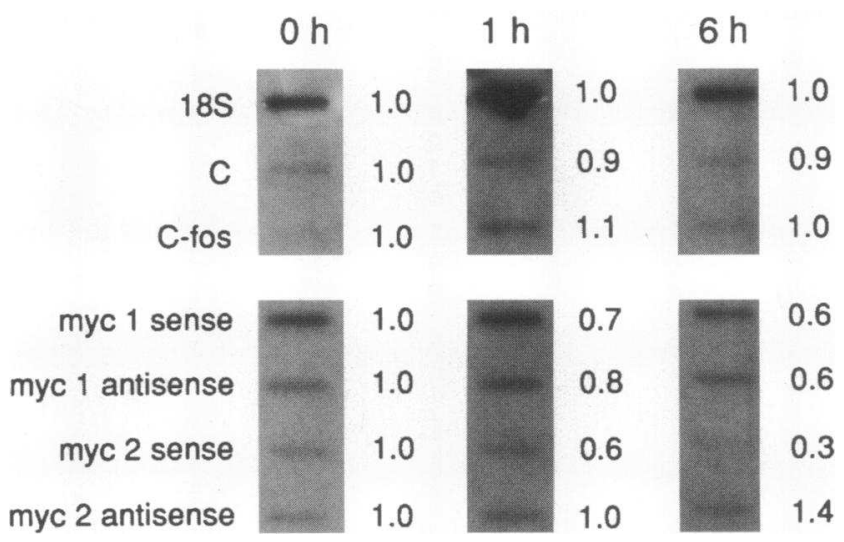

Figure 4. Transcription runoff assay. Transcription runoff analysis was performed as indicated in the Methods Section. Nuclei were isolated after exposure to dibutyryl cyclic AMP ( $1 \mathrm{mM}$ ) for the times indicated. Each slot represents $2 \mu \mathrm{g}$ of cDNA except for $18 \mathrm{~S}$ which is $200 \mathrm{ng}$ per slot. Densitometric quantitation was performed by normalizing the absorbance to the $18 \mathrm{~S}$ band for each strip and subsequently the absorbance of the exponential band was set at 1.0. Control cDNA is the Bluescript vector without an insert. A c-fos probe is also shown for comparison.

2 in the sense orientation indicating a modest decline in transcriptional initiation and a slight block to transcriptional elongation. Attenuation became more pronounced at $6 \mathrm{~h}$ of exposure to cyclic AMP. There was also a modest decline in the antisense transcription from exon 1 but not from exon 2 .

cAMP in 549 versus CEM Cells. We investigated cyclic AMP sensitivity in human T lymphoblast cell lines and determined that MOLT 4 cells like $\$ 49$ cells are inhibited by cyclic AMP (data not shown). By contrast, CEM cells like $\mathrm{KIN}^{-}$are resistant to agents that elevate intracellular cyclic AMP including dibutyryl cyclic AMP, RO-20-1724 (a phosphodiesterase inhibitor) (data not shown) and forskolin, an activator of adenylcyclase. As shown in Fig. 5 S49 cells are arrested in the G1 phase of the cell cycle by $1 \mathrm{mM}$ dibutyryl cyclic AMP for 24 $\mathrm{h}$. While completely viable at $24 \mathrm{~h}$ their survival at $72 \mathrm{~h}$ is profoundly reduced. By contrast, CEM cells have virtually no alteration in cell cycle distribution and virtually no reduction in survival at concentrations of dibutyryl cyclic AMP necessary to arrest $\mathrm{S} 49$ cells $(100 \mu \mathrm{M})$.

c-myc in S49 versus CEM Cells. Surprisingly, CEM cells appear to regulate c-myc message in much the same manner as S49 cells. The amount of c-myc message is increased in CEM cells relative to $S 49$ cells but the half-life, as measured by actinomycin D treatment, is only slightly prolonged in CEM cells by Northern blot analysis (Fig. $6 C$ ). Cyclic AMP has similar effects on c-myc message in S49 versus CEM cells again demonstrating a half-life of 20 to $40 \mathrm{~min}$. (Fig. $6 \mathrm{~A}$ ). Pretreatment with cycloheximide $(3 \mathrm{~h})$ increases the half-life suggesting protein synthesis is necessary to transduce part of the cyclic AMP effect (Fig. $6 B$ ). A very interesting phenomena occurs when dibutyryl cyclic AMP is added to actinomycin D treated cells. In S49 cells the combination of actinomycin D and cyclic AMP has little effect or perhaps shortens the halflife of c-myc messenger RNA whereas in CEM cells it vastly prolongs the c-myc message half life (Fig. $6 \mathrm{D}$ ). When the half-life of c-myc messenger RNA is determined by the RNase protection assay the rate of diminution is somewhat slower in CEM cells than S49 cells (Fig. 3, graph at the bottom) probably 


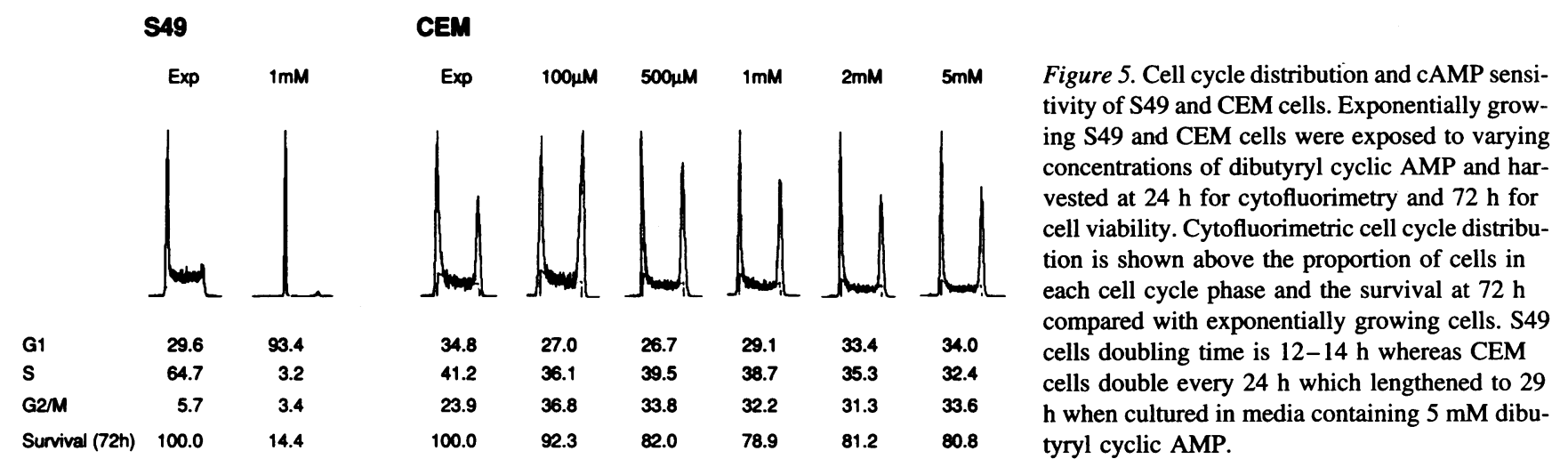

because the assay is more sensitive. In most experiments the cmyc expression in CEM cells treated with dibutyryl cAMP is undetectable at $24 \mathrm{~h}$ by RNase protection when the cells are still proliferating.

S49 wild type versus the "Deathless" mutant. We also compared these cell lines to the mutant S49 cell line called Deathless $\left(D^{-}\right)$that will arrest in $G 1$ phase (Table I) but which is viable during prolonged exposure to agents that elevate cyclic AMP (Table II). Deathless has similar viability to cyclic AMP elevation as $\mathrm{S} 49$ cells that have defects in the PKA phosphorylation pathway. Interestingly, all of the S49 derived cell lines
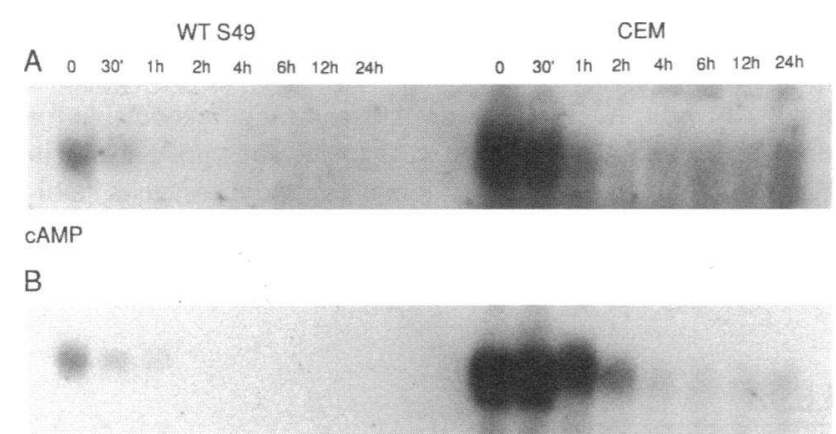

cAMP plus cyclohexamide

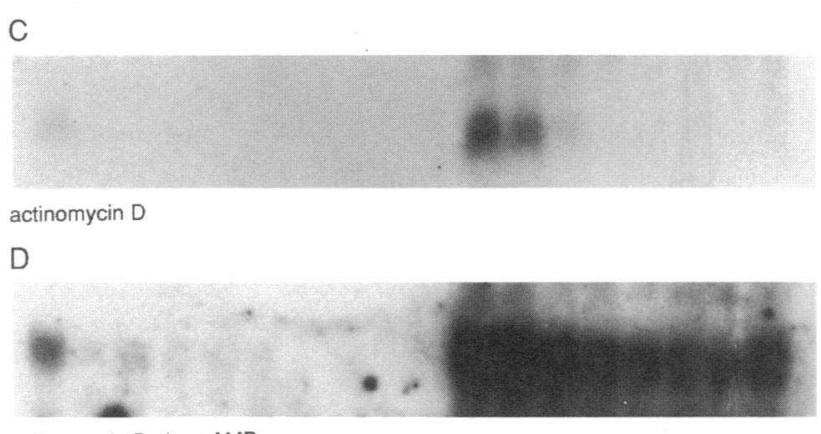

actinomycin D plus CAMP

Figure 6. c-myc Gene Expression in S49 versus CEM T lymphoma cells exposed to cyclic AMP, actinomycin D and cycloheximide. Northern blot analysis was performed on S49 or CEM cells at time points indicated after exposure to dibutyryl cyclic AMP $(1 \mathrm{mM})$ alone $(A)$ or after pre-exposure $(3 \mathrm{~h})$ to cycloheximide $(B)$ actinomycin $\mathrm{D}(5 \mu \mathrm{g} /$ $\mathrm{ml}$ ) alone $(C)$ or with dibutyryl cyclic AMP $(D)$. Equivalent loading and transfer was determined by hybridization with an $18 \mathrm{~S}$ mouse RNA probe filtered by densitometry. There was < $10 \%$ variation in $18 \mathrm{~S}$ RNA hybridization by densitometry.

(wild type, $\mathrm{KIN}^{-}$and $\mathrm{D}^{-}$) are sensitive to dexamethasone whereas, our CEM cells are not (20). Comparing c-myc expression in S49 wild-type versus Deathless during cyclic AMP induced cell cycle arrest reveals a sharp decline in c-myc messenger RNA concentrations during G1 cell cycle arrest in wildtype cells, whereas, c-myc expression from both the P1 and P2 promoter persisted for at least $24 \mathrm{~h}$ in Deathless (Fig. 7).

\section{Discussion}

Earlier observations on the effect of cyclic AMP on S49 T lymphocytes suggested that ribonucleotide reductase, a late G1 message, was transcriptionally inactivated by cyclic AMP (16). In preliminary studies, I investigated other genes expressed earlier in $\mathrm{G} 1$ phase to determine if events prior to the expression of ribonucleotide reductase are affected by cyclic AMP. The survey included c-fos, v-ki-ras, egr-1, c-myb and c-mos. There was no detectable expression of egr-1 in S49 cells and there was no difference in expression of v-ki-ras, c-myb or c-mos between exponentially growing S49 cells and cyclic AMP induced G1 arrested S49 cells. Others have shown a decrease in c-Ki-ras and c-myb as well as c-myc in glucocorticoid treated cells (21). There is a $50 \%$ decline in c-fos message during cyclic AMP induced G1 arrest. These results contrast with the dramatic decline in c-myc message during G1 arrest. Since $M y c$ protein is also short lived (22), these observations led us to the hypothesis that cyclic AMP cell cycle arrest is the result of inhibition of c-myc gene expression. The c-myc protein product is thought to be a transcriptional activator (at least when heterodimerized with MAX) and necessary for proliferation. Indeed, in some cell lines excessive expression of c-myc is associated with increased viability and constitutive expression of ornithine decarboxylase mRNA (23). This hypothesis might, in turn, account for the decreased transcription of the genes encoding the two subunits of ribonucleotide reductase. This hypothesis

Table I. Percent of Cells in Gl Phase

\begin{tabular}{lcc}
\hline & Control & dbcAMP (1 mM) \\
\hline CEM & 57.0 & 61.5 \\
S49WT & 54.2 & 85.2 \\
D $^{-}$ & 37.5 & 84.2 \\
KIN $^{-}$ & 38.2 & 37.9 \\
\hline
\end{tabular}


Table II. Survival at $72 h\left(E C_{50}\right)$

\begin{tabular}{lrcr}
\hline & dbcAMP & Dexamethasone & Forskolin \\
\hline & $\mu M$ & $n M$ & $\mu M$ \\
CEM & 1,800 & $>7,200$ & 87 \\
S49WT & 70 & 38 & 8 \\
D $^{-}$ & 450 & 14 & 50 \\
KIN $^{-}$ & 780 & 23 & 300 \\
& & & \\
\hline
\end{tabular}

was investigated by analyzing the mechanism of cyclic AMP inhibition of c-myc gene expression in a variety of different $\mathrm{T}$ lymphoma cell lines.

The expression of c-myc is an attractive target for cyclic AMP cell cycle arrest since it is closely linked to lymphoid cell proliferation. For example, c-myc dysregulation is associated with transformation of lymphoid malignancies and c-myc is expressed early in the mitogenic response of lymphocytes. Suppression of c-myc expression by antisense oligo nucleotides can inhibit entry into $S$ phase (24). More recently, it has become clear that uncontrolled c-myc expression, while hastening the cell cycle through G1 phase shortening, (25) leads to apoptosis. The mechanism of c-myc induced apoptosis is unknown but can be prevented by the $b c l-2$ gene that encodes a mitochondrial protein. The physiologic down-regulation of c-myc involves the FOS protein which binds to a negative regulatory sequence in the c-myc promoter $(26,27)$.

I confirmed the observations of others that the c-myc gene is expressed at relative stable levels through the cell cycle (28). However, the precipitous decline in c-myc gene expression before any change in cell cycle distribution, coupled with the return of c-myc expression soon after removal of cyclic AMP and before $\mathrm{G} 1$ exit suggests that c-myc gene expression might indeed be closely linked to $\mathrm{G} 1$ cell cycle arrest. This hypothesis is strengthened by the uniform correlation of persistent c-myc gene expression with cyclic AMP resistance in S49 $\mathrm{T}$ lymphoma mutant cell lines with deficient PKA activity.

Given the similarity of c-myc messenger RNA concentrations when cells are exposed to cyclic AMP or actinomycin D, I was surprised by the results of the transcription run-off studies. Based on previous studies by numerous investigators I expected that the mechanism of cyclic AMP inhibition of c-myc gene expression would be attenuation (29-33) which usually occurs at the end of the first exon (34) (that is unexpressed) although has been reported to occur between the $\mathrm{P} 1$ and $\mathrm{P} 2$ promoter $(35,36)$.

The transcription run-off studies however show no significant attenuation for several hours, which is well beyond the time period when c-myc message concentrations become undetectable. By $1 \mathrm{~h}$ there appears to be a 30\% decline in transcriptional initiation and an additional $10 \%$ decrease in transcript elongation. At this point the message concentration is virtually undetectable suggesting that cyclic AMP affects c-myc message stability in S49 cells. Since c-myc mRNA stability may be altered by protein binding, PKA dependent phosphorylation could influence this effect. A similar effect has been noted in glucocorticoid treated T lymphoma cells (37).

The prolongation c-myc message with cycloheximide pretreatment is expected since a number of rapidly turned over transcripts are stabilized by protein synthesis inhibition (38). However, the divergent response of S49 cells and CEM cells to the combination of actinomycin D and dibutyryl cyclic AMP is unanticipated. In S49 cells the two agents may be additive which would be consistent with cyclic AMP induced message degradation whereas in CEM cells the effect is the opposite. Clearly, if cyclic AMP phosphorylates a protein responsible for c-myc degradation in S49 cells that event does not happen in CEM cells. In fact, under these conditions the message is stabilized.

The observation that CEM cells respond to cyclic AMP by

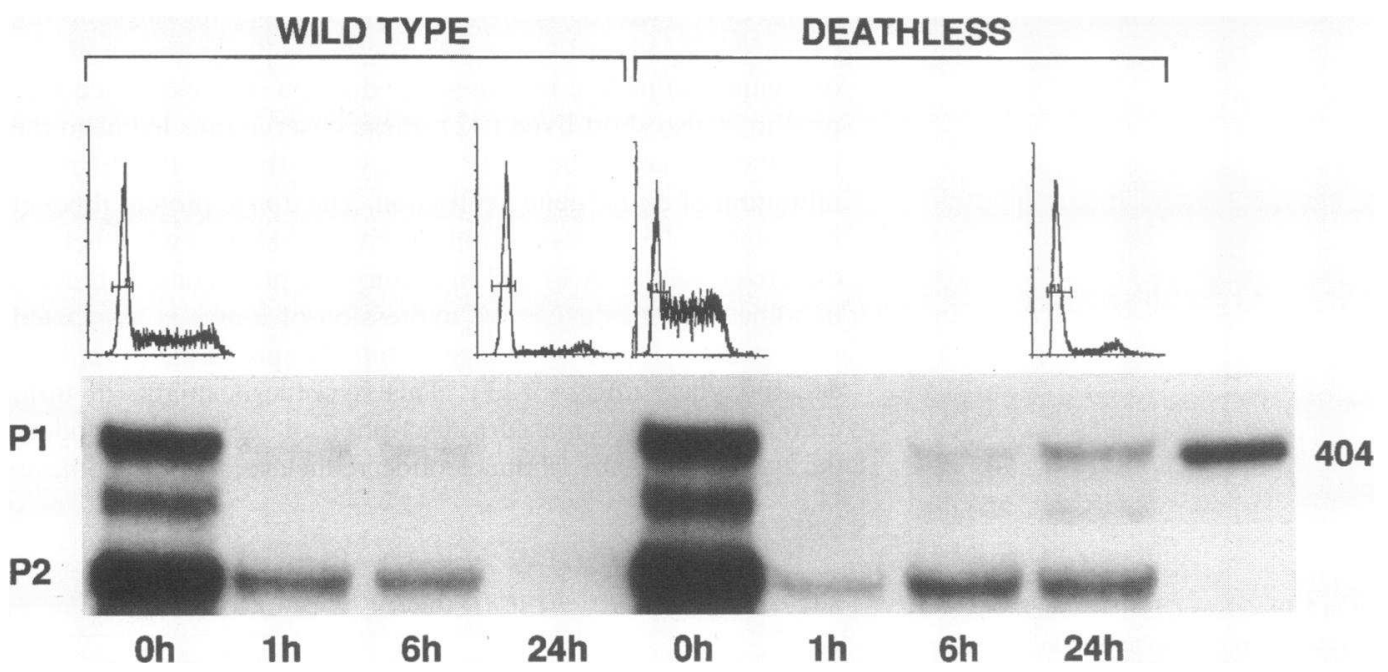

Figure 7. c-myc gene expression in wild-type S49 T lymphoma cells versus the mutant S49 cell line "Deathless" ( $\left.D^{-}\right)$. Cultures containing 5 $\times 10^{7}$ cells were exposed to dibutyryl cAMP $(1 \mathrm{mM})$ for the times shown then harvested for RNA extraction. Aliquots were stained with propidium iodide for cytofluorimetry. The proportion of cells in G1 phase was 54\% (wild type- $0 \mathrm{~h}$ ); $85 \%$ (wild type-24 h); $38 \%$ (Deathless- $0 \mathrm{~h}$ ); $84 \%$ (Deathless-24 h). The RNase protection assay was performed as described for Fig. 3. When adjusted for variation in loading there was a steep decline in c-myc expression in wild-type cells to undetectable levels at $24 \mathrm{~h}$, whereas in Deathless cells, there is persistance of c-myc expression during G1 arrest. 
diminishing c-myc gene expression while continuing to proliferate, calls into question the role of c-myc gene expression in $\mathrm{T}$ lymphocyte proliferation. Clearly, this line of $\mathrm{T}$ lymphoma cells appears to not require c-myc gene expression for continued proliferation, although we cannot exclude the possibility that very small amounts of $c-m y c$ messenger RNA persist and are adequate to permit proliferation. Conversely, continued expression of c-myc can occur under circumstances when the cells are growth arrested. For example, CEM cells exposed to cyclic AMP and actinomycin D continue to express c-myc but are growth inhibited (as in Fig. $6 \mathrm{D}$ ). Thus, c-myc expression appears to be neither necessary nor sufficient for CEM lymphocyte proliferation. Perhaps, there is some redundancy in the transcriptional activation that the MYC protein normally provides which would permit CEM cells to circumvent the cyclic AMP effect. Other members of the myc family, such as $\mathrm{N}-m y c$, which is known to be expressed in CEM cells (39), could provide this function. Further study will be necessary to determine if this hypothesis is valid. Alternatively, these CEM cells may have a block distal to the purported convergence point between cyclic AMP and glucocorticoid induced apoptosis (15) since this cell line is resistant to both agents (see Table II) although some CEM cell lines are sensitive to glucocorticoids (20). By contrast, Deathless is sixfold resistant to dbcAMP and Forskolin but sensitive to Dexamethasone (Table II). However, Deathless arrests in G1 phase as readily as wild-type S49 cells (Table I). Thus, G1 cell cycle arrest is not always associated with decreased c-myc expression and, conversely, decreased c-myc expression is not always associated with $\mathrm{G} 1$ cell cycle arrest.

While c-myc down-regulation and cyclic AMP cell cycle arrest could be mechanistically related in some cell types, it could be a protective rather than cytotoxic effect. Persistant cmyc expression is linked to apoptosis and, by contrast, cAMP G1 arrest is reversible (at least initially). It is possible that cAMP G1 arrest is a physiologic mechanism to down regulate lymphocyte proliferation and the down-regulation of c-myc expression prevents cell death and permits reversal. Preliminary data from our laboratory which supports this hypothesis is that constitutive expression of c-myc may be lethal to S49 cells. Analogous experiments in a human pre-B cell line Reh have also shown that constitutive expression of c-myc did not reverse cAMP-induced cell cycle arrest (40). Inducible expression of introduced vectors encoding the c-myc protein may help answer the question of whether cyclic AMP G1 cell cycle arrest in S49 cells is mechanistically linked to c-myc gene expression.

However, comparison of c-myc expression in S49 wild type cells with the Deathless mutant (41) clearly indicate that c-myc down regulation is not an absolute requirement for $\mathrm{G} 1$ cell cycle arrest in S49 cells. Furthermore, it suggests that c-myc downregulation may be more closely associated with apoptosis than cell cycle arrest. In summary, the relationship of c-myc expression to cell cycle progression and viability is complex and appears to vary between cell types even within the lymphoid lineages. In S49 mouse T lymphoma cells cyclic AMP downregulation of c-myc expression appears to be more closely related to a loss of viability than G1 cell cycle arrest.

\section{Acknowledgments}

Jaya Kuchibotla and Holly Peng participated in preliminary experiments in this project. Edwardine Nodzenski provided technical assistance. The RNase protection assays were performed by Andrew Wagner and Ed
Desjardins (Department of Pharmacology and Physiology, University of Chicago). We thank Nissim Hay for his comments and suggestions. The single stranded c-myc probes were provided by David Bentley (ICRF, London).

Support for these investigations was provided by the Arthritis Foundation of Illinois.

\section{References}

1. Kato, G. J., W. M. F. Lee, L. Chen, and C. V. Dang. 1992. Max: Functional domains and interaction with c-myc. Genes \& Dev. 6:81-92.

2. Blackwood, E. M., and R. N. Eisenman. 1991. Max: A Helix Loop-Helix zipper protein that forms a sequence-specific DNA-binding complex with $M y c$. Science (Wash. DC). 251:1211-1217.

3. Kelly, K., B. H. Cochran, C. D. Stiles, and P. Leder. 1983. Cell specific regulation of the c-myc gene by lymphocyte mitogens and platelet derived growth factor. Cell. 35:603-610.

4. Spencer, C. A., and M. Groudine. 1991. Control of c-myc Regulation in Normal and Neoplastic Cells. Adv. Cancer Res. 56:1-48.

5. Hay, N., J. M. Bishop, and D. Levins. 1987. Regulatory elements that modulate expression of human c-myc. Genes \& Dev. 1:659-671.

6. Moberg, K. H., T. J. Logan, W. A. Tyndall, and D. J. Hall. 1992. Three Distinct Elements within the murine c-myc promoter are required for Transcription. Oncogene. 7:411-416.

7. Duyao, M. P., A. J. Buckler, and G. E. Sonenshein. 1990. Interaction of an NF-KB-like factor with a site upstream of the c-myc promoter. Proc. Natl. Acad. Science USA. 87:4727-4731.

8. Cole, M. D. and S. E. Mango. 1990. Cis-acting Determinants of c-myc mRNA Stability. Enzyme. 44:167-180.

9. Dani, C. H., J. M. Blanchard, M. Piechaczyk, S. El-Sabouty, L. Marty, and $\mathrm{Ph}$. Jeanteur. 1984. Extreme instability of $m y c \mathrm{mRNA}$ in normal and transformed human cells. Proc. Natl. Acad. Sci. USA. 81:7046-7050.

10. Bissonnette, R. P., F. Echeverri, A. Mahboubi, and D. R. Green. 1992. Apoptotic cell death induced by c-myc is inhibited by bcl-2. Nature (Lond.). 359:552-554.

11. Wagner, A. J., M. B. Small, and N. Hay. 1993. Myc-mediated apoptosis is blocked by ectopic expression of Bcl-3. Mol. Cell. Biol. 13:2432-2440.

12. Montminy, M. R. and L. M. Bilezikjian. 1987. Binding of a nuclear protein to the cyclic-AMP response element of the Somatostatin gene. Nature (Lond.). 328:175-178.

13. Meinkoth, J. L., M. R. Montminy, J. S. Fink, and J. R. Feramisco. 1991. Induction of a cyclic AMP-responsive gene in living cells requires the nuclear factor CREB. Mol. Cell. Biol. 11:1759-1764.

14. Coffino, P., H. R. Bourne, and G. M. Tompkins. 1975. Cyclic AMP, a nonessential regulator of the cell cycle. Proc. Natl. Acad. Sci. USA. 72:878-882.

15. Dowd, D. R., and R. L. Miesfield. 1992. Evidence that glucocorticoid and cyclic AMP-induced apoptotic pathways in lymphocytes share distal events. Mol. Cell. Biol. 12:3600-3608.

16. Albert, D. A., and E. Nodzenski. 1992. Ribonucleotide reductase gene expression during cyclic AMP-induced cell cycle arrest in T lymphocytes. Exp. Cell Res. 203:476-482.

17. Marzluff, W. F. 1978. Methods Cell Biol. 19:317-331.

18. Zinn, K., D. Di Maio, and T. Maniatis. 1983. Identification of two distinct regulatory regions adjacent to the human $\beta$ interferon gene. Cell. 34:805-879.

19. Feinberg, A. P. B. and Vogelstein. 1983. A Technique for Radiolabeling DNA Restriction Fragments to High Specific Activity. Anal. Biochem. 132:6-13. 19a. Albert, D. A., J. Kowalski, E. Nodzenski, D. Lancki, and F. Fitch. 1990. The effect of cyclic AMP on proliferation of cloned T lymphocytes. Clin. Res. 38:545a. (Abstr.)

20. Yuh, Y. S., and C. B. Thompson. 1992. Glucocorticoid Effect on Oncogene/Growth Gene expression in Human T lymphoblastic Leukemic Cell Line CCRF-CEM. J. Biol. Chem. 264:10904-10912.

21. Eastman-Reks, S. B., and W. V. Vedeckis. 1986. Glucocorticoid Inhibition of c-myc, c-myb and c-ki-ras Expression in a Mouse Lymphoma Cell Line. Cancer Res. 46:2457-2462.

22. Rabbitts, P. H., J. V. Watson, A. Lamond, A. Foster, M. A. Stinson, G. Evan, W. Fischer, E. Atherton, R. Sheppard, and T. H. Rabbitts. 1985. Metabolism of c-myc gene products: c-myc mRNA and protein expression in the Cell Cycle. EMBO (Eur. Mol. Biol. Organ.) J. 4:2009-2013.

23. Dean, M., J. L. Cleveland, V. R. Rapp, and J. N. Ihle. 1987. Role of $m y c$ in the Abrogation of IL3 Dependence of Myeloid FDC-P1 Cells. Oncogene Res. 1:279-296.

24. Heikkila, R., G. Schwab, E. Wickstrom, S. L. Loke, D. H. Pluznik, R. Watt, and L. M. Neckers. 1987. A c-myc antisense oligodeoxynucleotide inhibits entry into $S$ phase but not progress from $G_{0}$ to $G_{1}$. Nature (Lond.). 328:445499.

25. Karn, J., J. V. Watson, A. D. Lowe, S. M. Green, and W. Vedeckis. 1989. Regulation of cell cycle duration by c-myc levels. Oncogene. 4:773-783. 
26. Takimoto, M., J. P. Quinn, A. R. Farina, L. M. Standt, D. Levens. 1989. fos/jun and Octamer-binding Protein Interact with a Common Site in a Negative Element of the Human c-myc Gene. J. Biol. Chem. 264:8992-8999.

27. Hay, N., M. Takimoto, and J. M. Bishop. 1989. A FOS Protein is present in a complex that binds a negative regulator of Myc. Genes \& Dev. 3:293-303.

28. Thompson, C. B., P. B. Challoner, P. E. Neiman, and M. Groudine. 1988 Levels of c-myc oncogene mRNA are invariant through the cell cycle. Nature (Lond.). 314:363-366.

29. Siebenlist, V., P. Bressler, and K. Kelly. 1988. Two Distinct Mechanisms of Transcriptional Control Operate on c-myc during Differentiation of HL-60 cells. Mol. Cell. Biol. 8:867-874.

30. Roberts, S. and D. Bentley. 1992. Distinct modes of Transcription read through or termination at the c-myc alternator. EMBO (Eur. Mol. Biol. Organ). J. 11:1085-1093.

31. Bentley, D. L., and M. Groudine. 1986. A block to elongation is largely responsible for decreased transcription of c-myc in differentiated HL-60. Nature (Lond.). 321:702-706.

32. Slungard, A., D. L. Confer, and W. H. Schubach. 1987. Rapid transcriptional down-regulation of c-myc expression during cyclic adenosine monophosphate promoted differentiation of leukemia cells. J. Clin. Invest. 79:1542-1547.

33. Trepel, J. B., O. R. Colamonici, K. Kelly, G. Schwab, R. A. Watt, E. A. Sausville, E. S. Jaffe, and L. M. Neckers. 1987. Transcriptional inactivation of c-myc and transferrin receptor in dibutyryl cyclic AMP-treated HL-60 cells. Mol. Cell. Biol. 7:2644-2688.
34. Eick, D. 1990. Elongation and Maturation of c-myc RNA is inhibited by differentiation inducing agents in HL-60 cells. Nucleic Acids Res. 18:1199-1205.

35. Wright, S., L. F. Mirels, M. C. B. Calayag, and J. M. Bishop. 1991. Premature termination of transcription from the P1 promoter of the mouse c-myc gene. Proc. Natl. Acad. Sci. USA. 88:11383-11387.

36. Meulin, T., A. Krumm, C. Spencer, and M. Groudine. 1992. Sequences in the human c-myc $\mathrm{P} 2$ promoter affect the elongation and premature termination of transcripts initiated from the upstream P1 promoter. Mol. Cell. Biol. 12:45904600.

37. Marodor, M., S. Martinotti, et al. 1990. Posttranscriptional control of c-myc protooncogene expression by glucocorticoid hormones in human $\mathrm{T}$ lymphoblastic leukemia cells. Nucleic Acid. Res. 18:1153-1153.

38. Cleveland, D. W., and T. J. Yen. 1989. Multiple determinants of eukaryotic mRNA stability. New Biol. 1:121-126.

39. Jucker, M., M. Schaadt, V. Diehl et al. 1990. Heterogeneous expression of protooncogenes in Hodgkins disease derived cell lines. Hematol-Oncol. 8:191204.

40. Andersson, K. O., A. Deggerdal, C. Skjonsberg, E. B. Smeland, and H. K. Blomhoff. 1993. Constitutive expression of c-myc does not relieve cAMPmediated growth arrest in human lymphoid Reh cells. J. Cell Physiol. 157:6169.

41. LeMaire, I., and P. Coffino. 1977. Cyclic AMP-Induced Cytolysis in S49 Cells: selection of an Unresponsive 'Deathless' Mutant. Cell. 11:149-155. 